\title{
Evidence on Otolith Structure and some Ecological Features of Three Small Foraging Species along the Southern Black Sea Coast
}

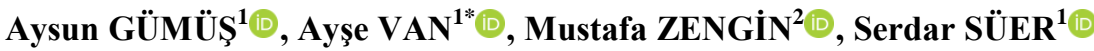 \\ ${ }^{1}$ Ondokuz Mayıs University, Faculty of Science and Arts, Department of Biology, Samsun, Turkey \\ ${ }^{2}$ Central Fisheries Research Institute, Department of Fisheries Management, Trabzon, Turkey
}

*Corresponding Author: van_55.1986@hotmail.com

Received 24 September 2020; Accepted 02 January 2021; Release date 01 June 2021.

How to Cite: Gümüş, A., Van, A., Zengin, M. \& Süer, S. (2021). Evidence on otolith structure and some ecological features of three small foraging species along the southern Black Sea coast. Acta Aquatica Turcica, 17(2), 267-278. https://doi.org/10.22392/actaquatr.799615

\begin{abstract}
In this study, we aimed to describe otoliths to provide information about the stomach contents of three small foraging species and to contribute to the currently limited biological and ecological evidence about the species. Seasonal experimental bottom trawl surveys were conducted along the shelf areas of the Kızılırmak-Yeşilırmak and Melet Rivers to collect investigation materials which were abundant in the bycatch composition of the target catch. The information about body size measurements, abundance values, depth, season, and locality of samplings was recorded for further evaluations. Otolith shapes were defined as discoidal to ovate for the Aphia minuta, discoidal for the Pomatoschistus marmoratus, and square for the Arnoglossus kessleri. The mean length and weight values of the Aphia minuta, which was abundant along shallow coastal waters $(0-30 \mathrm{~m})$, were significantly different between localities and sampling season, but no difference was found between depth ranges. Pomatoschistus marmoratus, whose distribution varied significantly between depths and seasons had dense distributions along with the depth range of 30-60 m. Arnoglossus kessleri was most abundant along with the depth range of 0$30 \mathrm{~m}$ and had no samples in depths of over $60 \mathrm{~m}$. It was found that the mean values of length and weight of this species were only significantly different among seasons but similar over the depth ranges and localities.
\end{abstract}

Keywords: Aphia minuta, Pomatoschistus marmoratus, Arnoglossus kessleri, abundance, Black Sea.

Güney Karadeniz kıyılarında dağılım gösteren üç küçük yem balığının otolit yapısı ve bazı ekolojik özelliklerine dair bilgiler

Özet

$\mathrm{Bu}$ çalışmada, üç küçük yem balığının mide içeriği çalışmalarına bilgi sağlamak için otolitlerinin tanımlanmasını ve bu türler hakkında halihazırda sınırlı olan biyolojik ve ekolojik bulgulara katkı sağlamak amaçlanmıştır. Hedef kompozisyonunda bol miktarda bulunan araştırma materyallerini toplamak için Kızılırmak-Yeşilırmak ve Melet Nehirleri şelf alanları boyunca mevsimsel deneysel dip trol surveyleri yürütülmüştür. Örneklemin, vücut boyutuna ait ölçümleri, bollukları, derinlik, mevsim ve lokalite bilgileri daha sonraki değerlendirmeler için kaydedilmiştir. Otolit şekilleri Aphia minuta için 'diskoidal oval, Pomatoschistus marmoratus için 'diskoidal' ve Arnoglossus kessleri için 'kare' olarak tanımlanmıştır. Sı̆̆ kıyı suları boyunca $(0-30 \mathrm{~m})$ bol miktarda bulunan Aphia minuta türünün ortalama boy ve ağırlık değerleri, lokaliteler ve örneklendiği mevsimler arasında önemli ölçüde farklılık gösterirken, derinlikler arasında fark bulunmamıştır. Dağılımı derinlikler ile mevsimler arasında anlamlı farklılık gösteren Pomatoschistus marmoratus, 30-60 m derinlik aralığında yoğun bir dağılım göstermektedir. Arnoglossus kessleri en fazla 0-30 m derinlik aralığında yoğundur ve $60 \mathrm{~m}$ üzerinde ise örneğe rastlanmamıştır. Bu türün ortalama boy ve ağırlık değerleri sadece mevsimler arasında önemli ölçüde farklı ancak derinlikler ve lokaliteler arasında ise benzerdir.

Anahtar Kelimeler: Aphia minuta, Pomatoschistus marmoratus, Arnoglossus kessleri, bolluk, Karadeniz

\section{INTRODUCTION}

Fishbones, otoliths, scales, vertebrae, teeth, eye lenses, and other soft tissue particles were removed from the stomachs or feces of sea mammals, sea birds, fish, and squid to identify the prey in diet composition studies (Battaglia et al., 2013; Elliott et al., 2015). Information derived from otoliths is a major tool in age, growth, population dynamics, and feeding studies. The otolith pairs asterisci and lapilli are quite small in size in most of the fish species and rarely used in stomach content research. The largest of the otolith pairs, sagitta, are the most frequently reported in the diet composition of 
marine organisms (Bethea et al., 2004; Elliott et al., 2015). Otoliths are primary structures and provide basic information for the identification of the type of prey consumed by marine piscivores (Fitch and Brownnell, 1968) as they have species-specific characteristics (Tuset et al., 2008). Since otoliths are slowly digested elements, not only the type of prey but also the size could be determined (Fitch and Brownnell, 1968).

There are numerous studies of the relationship between otolith and body size (Viva et al., 2015), providing data for a robust estimation of the length and weight of the foraging species (Aguilar-Perera and Quijano-Puerto, 2016). This has become another requirement for otolith atlases and guides about morphology and morphometry to enable the identification of the stomach contents of the piscivorous marine organism throughout their life histories (Baremore and Bethea, 2010; Lin and Chang, 2012).

The three species investigated in this study are the transparent goby, Aphia minuta (Risso, 1810); the marbled goby, Pomatoschistus marmoratus (Risso, 1810); and the scaldback, Arnoglossus kessleri Schmidt, 1915. None of the three species are targeted by any fisheries on the southern Black Sea coast, but they are known to be important components of bycatch in bottom trawl fishery (KARTRIP, 2013). Though they have no commercial value, they play ecologically significant roles as being the prey of carnivores in the ecosystem. The otolith atlas of Black Sea fish fauna (Kasapoglu and Duzgunes, 2015) includes no information about the transparent goby marbled goby or the scaldback. When stomach content studies conducted along the Black Sea coasts were reviewed (Avsar, 2001; Engin and Seyhan, 2010; Samsun et al., 2011; Kaya and Saglam, 2017), it was observed that most of the small pelagics (e.g. anchovy, sprat, and horse mackerel) and the small benthopelagic species (e.g. red mullet and gobies) were reported as the fish prey groups, but there is no study recording these three species as prey. These species are also known for their schooling habits which promote them being preyed upon by other predators (Breitburg, 1991; La Mesa et al., 2005; KARTRIP, 2013). A lack of record of these three species as prey substances in feeding studies maybe because their otoliths could not be identified in stomach contents, or their otoliths were misidentified as anchovy or sprat.

The transparent goby is a small, neritic, and widespread species (Chesalin et al., 2004). This species inhabits coastal areas, estuaries, and freshwater. And, unlike other gobiid species, they occur in the pelagic zone (Miller, 1986a). Though it has no commercial value in the Black Sea fishery, it is a target species and provides substantial income in western and central Mediterranean artisanal and small-scale fisheries (La Mesa et al., 2005). In the Black Sea, Fortunatova (1949) recorded demersal species such as Merlangius merlangus, Mullus barbatus, Platichthys flesus, Scorpaena porcus, Solea spp., and Trachinus spp. as the predators of the transparent goby. However, it is also highly possible that Trachurus mediterraneus, Pomatomus saltatrix, and Alosa immaculata are potential predators since they have been caught with the transparent goby in the same trawl hauls (KARTRIP, 2013).

The marbled goby is a small demersal species, mostly inhabiting lagoon, estuarine, and coastal waters and distributed along eastern Atlantic waters: the Mediterranean, Black, Azov, and Aegean Seas; and the Suez Canal (Malavasi et al., 2005; Apostolou et al., 2011). Mostly appearing in shallow waters and tolerating low and high salinities, it is also observed around $70 \mathrm{~m}$ depth in winter in the Black Sea (Miller, 1986b; Apostolou et al., 2011).

The scaldback is a benthic species distributed along the Black, Marmara, Aegean, and Levantine Seas (Nielsen, 1986; Bilecenoglu et al., 2014). It is not a target species in Black Sea fisheries and mostly appears in bycatch compositions. Besides not being a common species, the information about the scaldback population is also limited. The Arnoglossus spp. is known as a foraging species and is preyed on by piscivorous demersal species (Bariche et al., 2009).

\section{MATERIALS and METHODS}

This study was conducted seasonally along the continental shelf of the southern-middle Black Sea within the Kizılırmak-Yeşilırmak shelf area (KYSA) and the Melet River shelf area (MSA) between 2010-2011. The KYSA is the major fishery area of the mid-east of the southern Black sea. The trawl fisheries have been active in this region for long years. The MSA has a narrower shelf area than the KYSA and is closed to commercial bottom trawl fishery. The KYSA and the MSA have similar ecosystem characteristics such as substrate type, currents, and being discharged by large rivers like the Kızılırmak, Yeşilırmak, Terme Stream, and Melet Rivers.

Six stations were defined in an east-west direction. In the MSA; the three of stations were named as follows: O1 (Melet River offshore), O2 (Perşembe), and O3 (Ünye port). In the KYSA, the other three 
stations were named as follows: S1 (Çaltıcape), S2 (Azot offshore), and S3 (Atakum-Dereköy) (Figure 1). The sampling depths were designed in three different ranges $(0-30 \mathrm{~m}, 30-60 \mathrm{~m}, 60+\mathrm{m})$ for each station. Two hauls were conducted to gain variation in each sampling coordinate. In total, 144 operations were completed for six stations, three depth zones, two repeated hauls, and four seasons. The experimental bottom trawl survey was performed by the "Sürat Araştırma-I" research vessel belonging to the Central Fisheries Research Institute (CFRI). The mesh size in the cod-end of the sampling gear was $13 \mathrm{~mm}$, known as a 'blind net'.

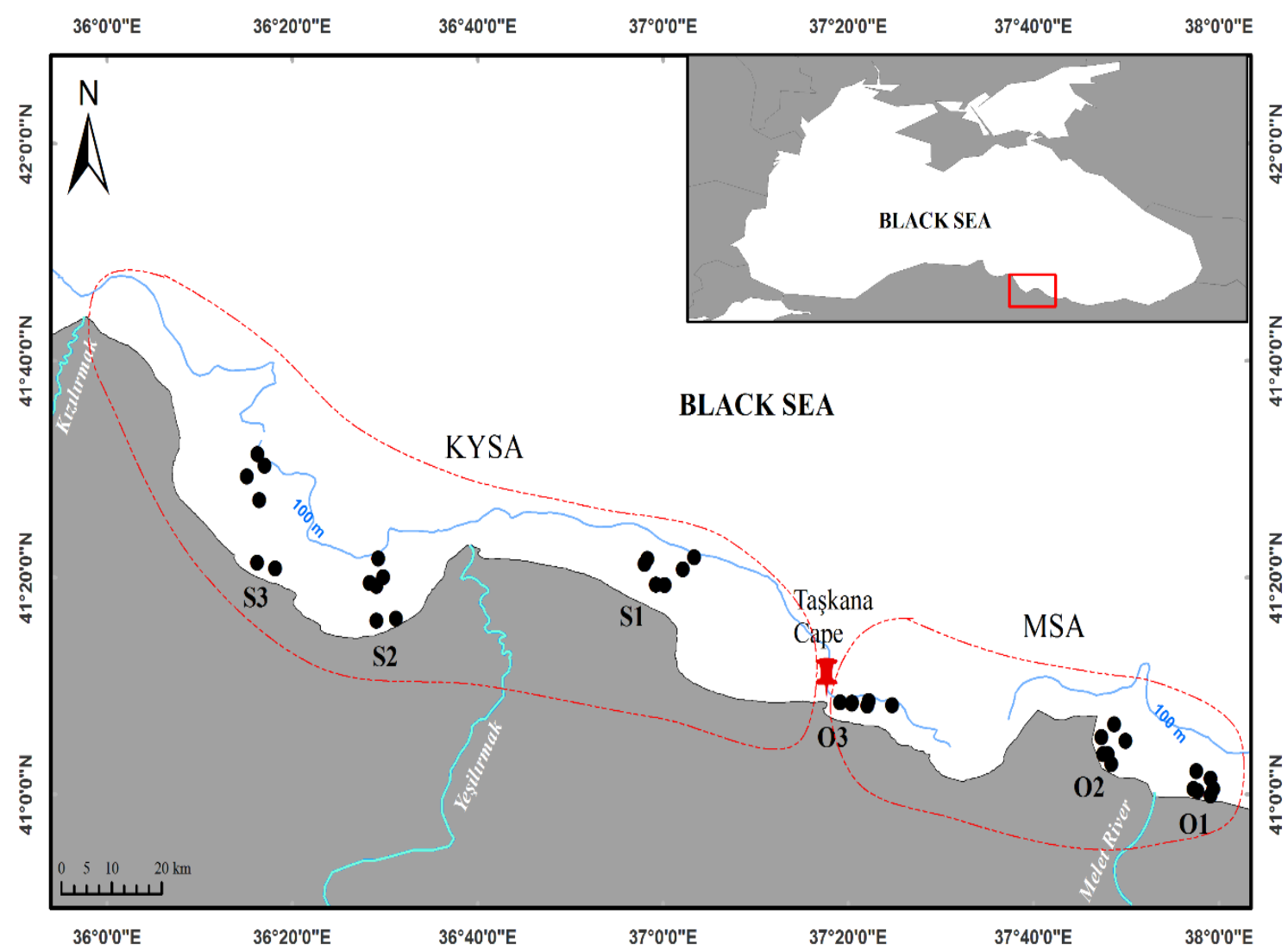

Figure 1. Map of the study area showing sampling locations

The individual total length $( \pm 0.1 \mathrm{~cm})$ and individual total weight $( \pm 0.01 \mathrm{~g})$ were measured. The otoliths were removed from specimens of three species using a dissection microscope since all fish species were too small for a routine otolith removal. The otoliths were cleaned and kept dry and were recorded by a Leica S8 APO stereo microscope attached to a camera (Leica DC 500) and an image analysis system (Application Suite Version 4.3.0). Campana (2004) and Tuset (2008) were taken as references when defining the otolith structure. The count of individuals for each species and each sampling were recorded and assessed for total catch for estimation of abundance $\left(\mathrm{N} . \mathrm{km}^{-2}\right)$. The lengthweight relationships were estimated by $\mathrm{W}=\mathrm{a} \times \mathrm{TL}^{\mathrm{b}}$ equation, where $\mathrm{W}$ is the total weight $(\mathrm{g})$, $\mathrm{TL}$ is the total length $(\mathrm{cm})$, $a$ is the intercept, and b is the slope (Froese, 2006). The mean values of total length and weight were tested for any significant difference between stations, depths, and seasons by means of a one-way analysis of variance (ANOVA) and a t-test. The swept area was calculated by the equation $\mathrm{a}=\mathrm{D} * \mathrm{hr} * \mathrm{X}^{2}$ where a is the area covered by the trawl, D is the distance covered, $\mathrm{hr}$ is the length of the head rope, $X^{2}$ is the fraction of the head rope length which is equal to the width of the path swept by the trawl; $\mathrm{D}=\mathrm{V} * \mathrm{t}$ where $\mathrm{V}$ is the velocity of the trawl over the ground while trawling, and $t$ is the hauling duration to estimate the abundance values (Sparre and Venema, 1992). All analyses were performed using SPSS v17.0.1, and the statistical significance was set at $p<0.05$. ArcGIS v9.2 was applied to form the maps of the species abundance distribution in the sampling area. 


\section{RESULTS}

\section{Transparent goby}

The transparent goby was sampled in both regions (KYSA and MSA) and six stations. The density map is presented in Figure. 2. Abundance values were estimated as $23.891\left(\mathrm{~N} . k m^{-2}\right)$ within a depth range of 0-30 m while it was $4.303\left(\mathrm{~N}_{\mathrm{km}}{ }^{-2}\right)$ within $30-60 \mathrm{~m}$. The abundance of the transparent goby calculated as $482.0 \mathrm{~N} \cdot \mathrm{km}^{-2}$ was relatively low at depths over $60 \mathrm{~m}$. The transparent goby exists in all stations from Samsun Atakum-Dereköy to Ordu-Melet River offshore in different intensities. The highest abundances were observed at $\mathrm{S} 2$ and $\mathrm{O} 3$ stations.

A total of 567 transparent goby individuals were obtained from the MSA $(\mathrm{N}=259)$ and the KYSA $(\mathrm{N}=308)$ stations. The length range was $2.9-5.8 \mathrm{~cm}$, and the weight range was $0.07-1.10 \mathrm{~g}$ for the pooled data. The mean total length was $4.14 \pm 0.03 \mathrm{~cm}$, and the mean weight was $0.37 \pm 0.01 \mathrm{~g}$ for the MSA while they were estimated as $3.99 \pm 0.02 \mathrm{~cm}$ and $0.34 \pm 0.08 \mathrm{~g}$ respectively for the KYSA. A significant difference was determined between the east and west locations in the mean values of both total lengths ( $\mathrm{t}$-test, $t=4.048, p<0.001)$ and weight ( $\mathrm{t}$-test, $t=2.279, p<0.05)$ revealing slightly larger individuals in the MSA location. Seasonal variations in mean values of total length (ANOVA, $F$ $(3.563)=163.637, p<0.001)$ and weight $(F(3,563)=267.629, p<0.001)$ of the transparent goby indicated a significant difference. The highest mean value of total length was recorded in the spring as $4.66 \pm 0.04 \mathrm{~cm}$ and the mean weight as $0.64 \pm 0.02 \mathrm{~g}$ where the lowest values were observed in fall as $3.57 \pm 0.03 \mathrm{~cm}$ and $0.19 \pm 0.01 \mathrm{~g}$ respectively. The post-hoc test (Tukey HSD) showed that the transparent goby is different in size in different seasons. There was no significant difference in the mean total length and weight between depth ranges (ANOVA, $F(2,564)=0.758, p>0.05$ ). However, there was a remarkable difference in species abundance in terms of depth. The L-W relationship of transparent goby revealed the parameters as $a=0.002$ and $b=3.751\left(b_{S E}=0.073\right)\left(r^{2}=0.82\right)$, implying a positive allometric type.

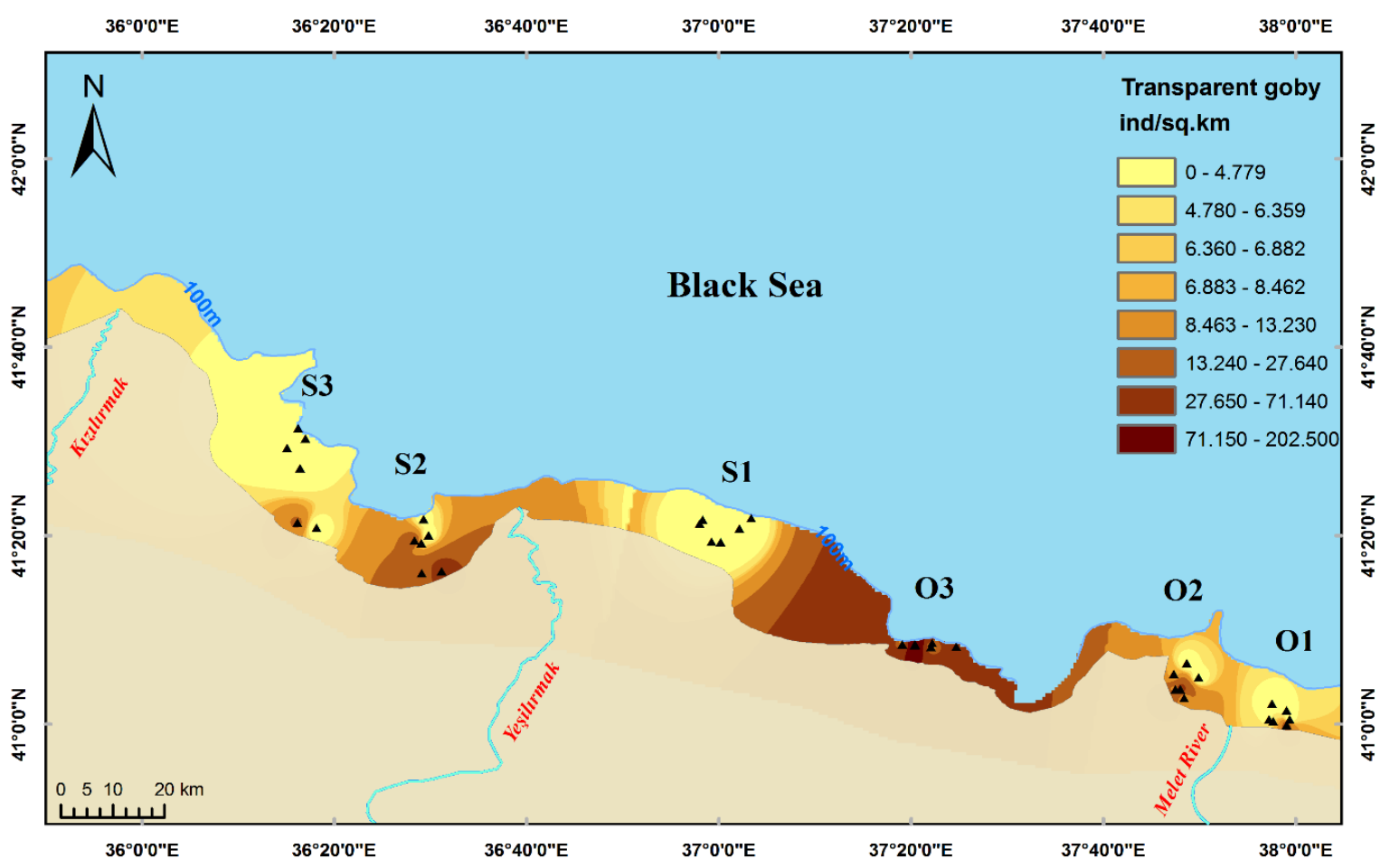

Figure 2. The mean density map of the transparent goby along MSA and KYSA shelf areas

The otolith of the transparent goby was quite small, discoidal to ovate, and extremely fragile (Figure 3) Its Sulcus acusticus can be defined as heterosulcoid, mesial, and ascending; its Ostium as round to oval, longer and wider than cauda, and not reaching to the anterior margin; and its Cauda as round to oval, not reaching the posterior margin. Growth rings are not very distinct but slightly visible on the axis through the rostrum and postrostrum. 


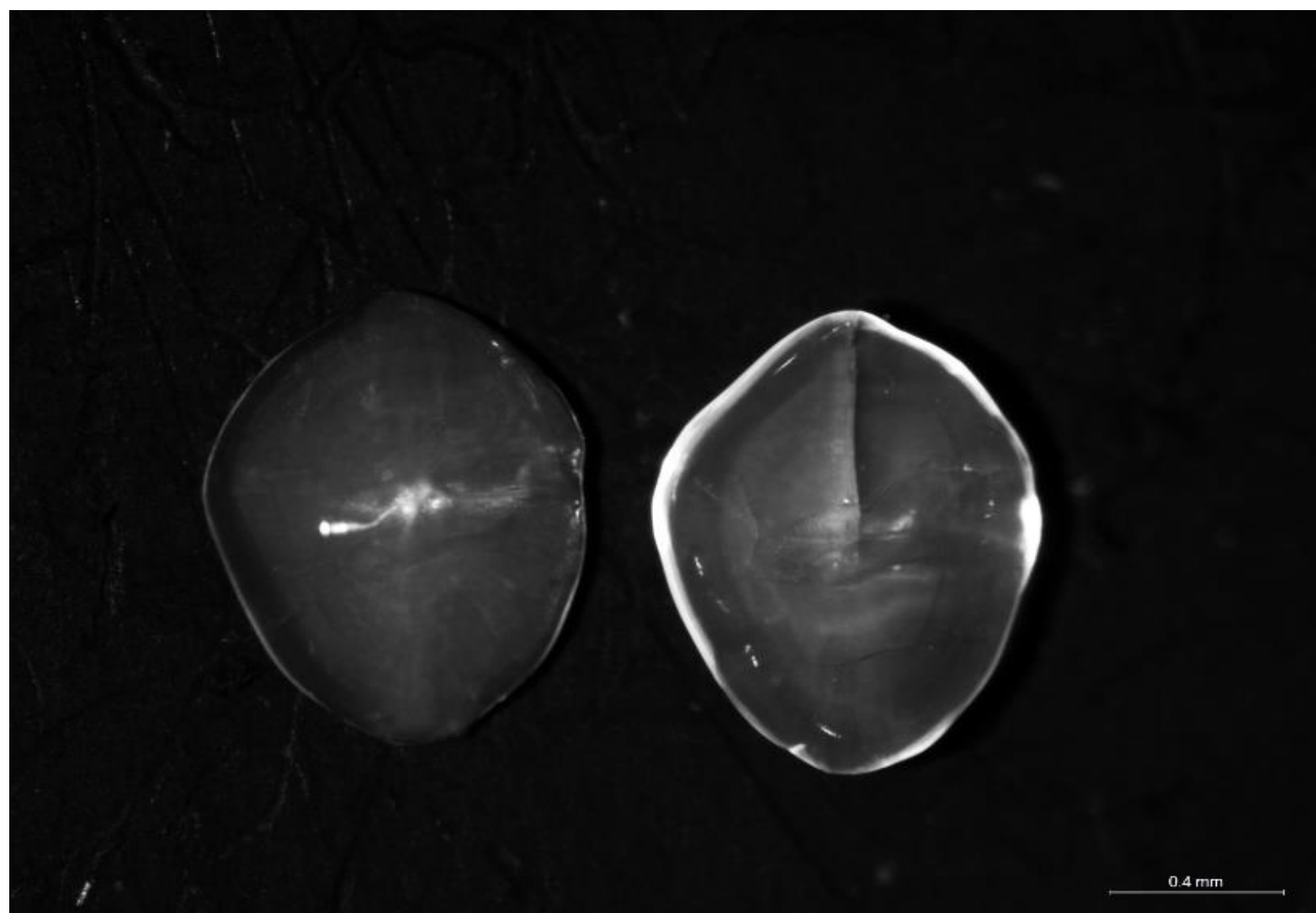

Figure 3. The morphology of the otolith of a transparent goby specimen ( $4.8 \mathrm{~cm}$ TL and $0.53 \mathrm{~g} \mathrm{~W}$ ) from distal and proximal surface (Otolith length $=0.996 \mathrm{~mm}$ and otolith width $=0.768 \mathrm{~mm}$ )

\section{Marbled goby}

The marbled goby was sampled from both the KYSA and the MSA at all stations. The distribution density map is shown in Figure 4. The mean density was estimated as $8326 \mathrm{~N} . \mathrm{km}^{-2}$, and the highest intensities were recorded at 30-60 m depth range. The mean densities were calculated as $2480 \mathrm{~N} . \mathrm{km}^{-2}$ for $0-30 \mathrm{~m}$ and $3885.7 \mathrm{~N} \cdot \mathrm{km}^{-2}$ for $60+\mathrm{m}$ depth ranges. The highest aggregation was determined at the S3 and S2 stations.

The biometric measurements of the total of the 716 individuals sampled indicated that the total length range in the marbled goby was between $2.5-6.5 \mathrm{~cm}$, and the weight ranged between $0.07-1.81 \mathrm{~g}$ for the pooled data. The mean total length was $4.41 \pm 0.05 \mathrm{~cm}$, and the weight was $0.59 \pm 0.02 \mathrm{~g}$ in the MSA stations where they were estimated as $4.470 \pm 0.03 \mathrm{~cm}$ and $0.64 \pm 0.01 \mathrm{~g}$ respectively for the KYSA stations. The mean total length and weight values for the MSA and the KYSA were not significantly different (in the t-test, for total length, $t=-1.068, p>0.05$ and for weight, $t=0.141, p>$ $0.05)$. The mean total length and weight in terms of seasons reached their maximum in the fall $(4.53 \pm 0.05 \mathrm{~cm}$ and $0.69 \pm 0.02 \mathrm{~g})$ and their minimum in the spring $(4.30 \pm 0.06 \mathrm{~cm}$ and $0.55 \pm 0.02 \mathrm{~g})$. ANOVA displays significantly different mean total length and weight values between seasons (ANOVA, $F(3,712)=4.492, p<0.05$ and ANOVA, $F(3,712)=8.137, p<0.001)$, respectively. The marbled goby showed a dispersion throughout all depth ranges. The mean total length and weight values were $4.07 \pm 0.04 \mathrm{~cm}$ and $0.48 \pm 0.02 \mathrm{~g}$ at depths of $0-30 \mathrm{~m}$ and $4.64 \pm 0.04 \mathrm{~cm}$ respectively, $0.70 \pm 0.02 \mathrm{~g}$ at $30-60 \mathrm{~m}$, and $4.74 \pm 0.06 \mathrm{~cm}-0.73 \pm 0.03 \mathrm{~g}$ at $60+\mathrm{m}$. The significantly different size values between the different depth ranges (ANOVA, $F(2,713)=67.766, p<0.001$ ) also implied that the individuals smallest in size were distributed in the waters near the shore. The parameters of the LW relationship were estimated as $a=0.005$ and $b=3.175\left(b_{S E}=0.04\right)\left(r^{2}=0.90\right)$, pointing to a positive allometry. 


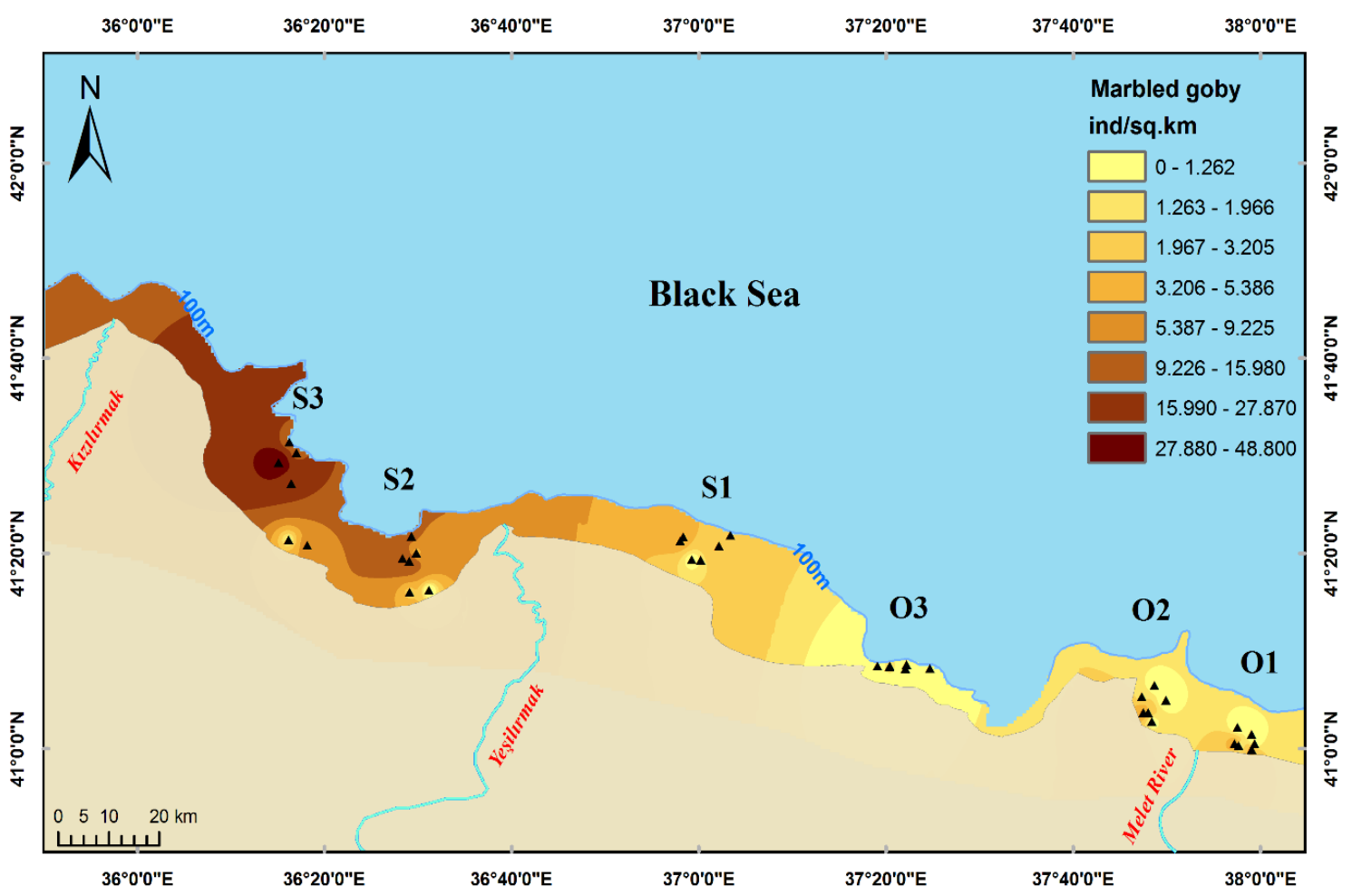

Figure 4. The mean density map of the marbled goby along MSA and KYSA shelf areas

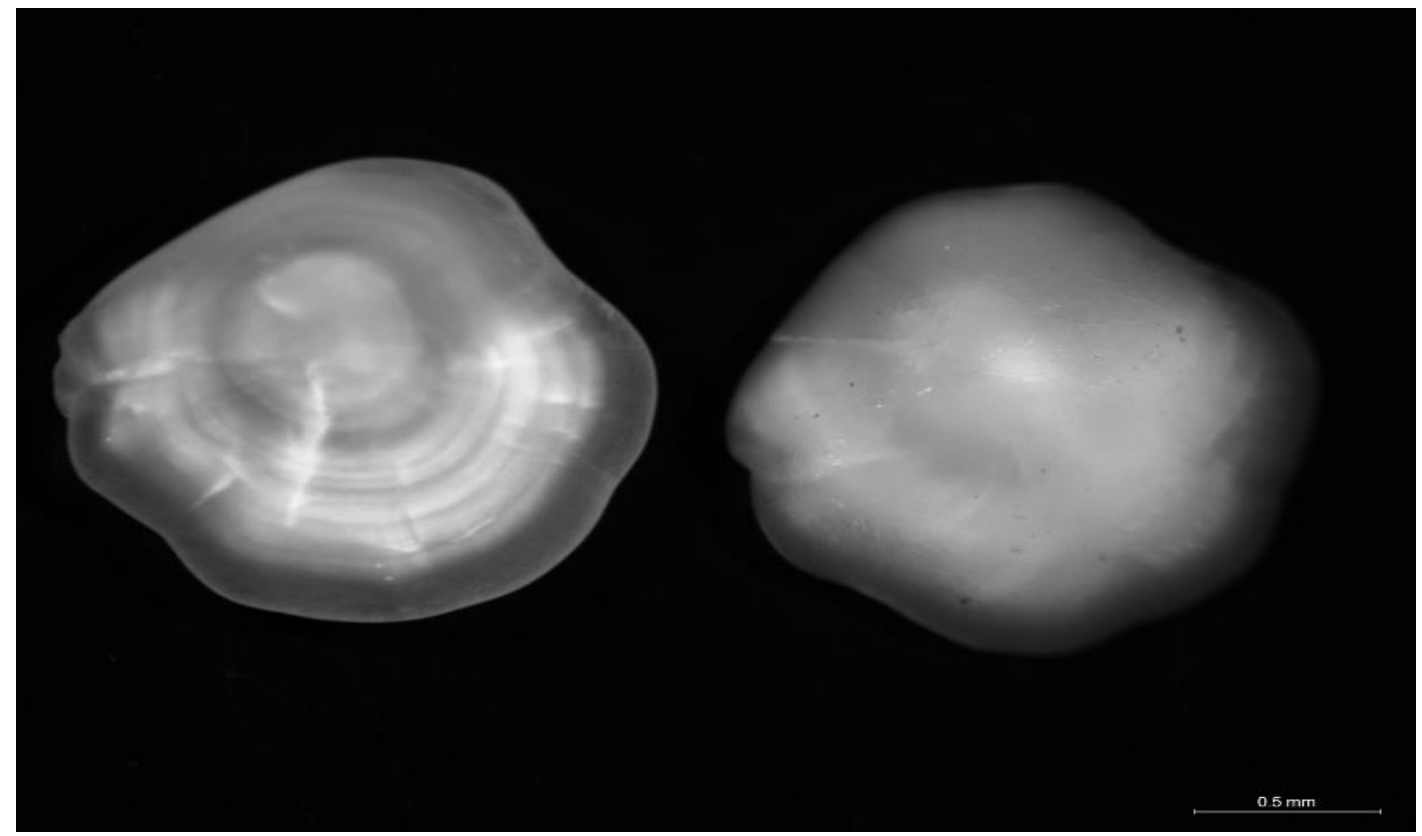

Figure 5. The morphology of the otolith of a marbled goby specimen ( $4.3 \mathrm{~cm} \mathrm{TL}$ and $0.54 \mathrm{~g} \mathrm{~W})$ from distal and proximal surface (Otolith length=1.494 $\mathrm{mm}$ and otolith width=2.008 $\mathrm{mm}$ )

The shape of marbled goby sagitta is discoidal, round in dorsal, and slightly undulated in the ventral region (Figure 5); round in the posterior and slightly peaked in the anterior region. The Sulcus acusticus is hardly visible, heterosulcoid, and mesial. Growth rings are distinctly visible on the distal surface. The sagittal core is clear and surrounded by hyaline and opaque concentric bands more widely spaced through the posterior axis.

\section{Scaldback}

The scaldback was sampled from all stations of the KYSA and the MSA except stations over $60 \mathrm{~m}$. Though it has been observed at a depth range of 30-60 m, the mean density value was as low as 101.5 
N.km ${ }^{-2}$. The highest mean density was estimated as $6643 \mathrm{~N} \cdot \mathrm{km}^{-2}$ at the depth range of 0-30 m. Figure 6 implies that the highest abundancies are at $\mathrm{S} 2, \mathrm{O} 2$, and $\mathrm{O} 1$.

The total length and total weight of the 528 scaldback specimens ranged from $2.9-12.8 \mathrm{~cm}$ and 0.03-16.70 g respectively for the pooled data. For the KYSA, the mean total length and weight was estimated as $5.19 \pm 0.07 \mathrm{~cm}$ and $1.43 \pm 0.07 \mathrm{~g}$ where they were $2.9-12.8 \mathrm{~cm}$ and $1.58 \pm 0.08 \mathrm{~g}$ respectively in the MSA. There was no significant difference between mean length (t-test, for length, $t=1.035, p>$ $0.05)$ and mean weight $(t=1.447, p>0.05)$ for the KYSA and the MSA. The summer $(5.39 \pm 0.07 \mathrm{~cm})$ and fall $(5.39 \pm 0.07 \mathrm{~cm})$ have the highest mean length values, and the maximum mean weight was observed in summer $(1.65 \pm 0.07 \mathrm{~g})$. The lowest mean length $(5.00 \pm 0.09 \mathrm{~cm})$ and weight $(1.27 \pm 0.09 \mathrm{~g})$ values were recorded in winter. The mean values were tested for any differences between seasons, and the following were determined to be significant: ANOVA, for length $F(3,524)=4.849, p<0.05$ and ANOVA, for weight $F(3,524)=2.751, p<0.05$. Scaldback individuals were not found within depths over $60 \mathrm{~m}$. However, dense aggregation was observed at a depth range of 0-30 m. The mean length and weight values were $5.20 \pm 0.04 \mathrm{~cm}$ and $1.44 \pm 0.04 \mathrm{~g}$ at $0-30 \mathrm{~m}$ depth and $7.29 \pm 0.996 \mathrm{~cm}$ and $4.92 \pm 1.737 \mathrm{~g}$ at $30-60 \mathrm{~m}(\mathrm{~N}=11)$, implying that individuals smaller in size are distributing along shallow waters while larger ones preferred the deeper zones. However, there was no significant difference between mean values for different depths (t-test, for length, $t=-2.096, p>0.05$ and $\mathrm{t}$-test, for weight, $t=-2.003, p>0.05)$. The estimated parameters of the L-W equation were $a=0.009$ and $b=$ $3.005\left(b_{S E}=0.05\right)\left(r^{2}=0.90\right)$, revealing an isometric relationship in the scaldback.

The sagitta of the scaldback is highly transparent, fragile, and square in shape; the Sulcus acusticus is heterosulcoid, median, and ostial (Figure 7). The Ostium is tubular, straight and longer than cauda reaching to the anterior margin. The Cauda is round-oval, rather short, and ending far from the posterior margin. Growth rings are not distinct and are hardly visible on the otolith surface towards the posterior margin in the dorsal direction.

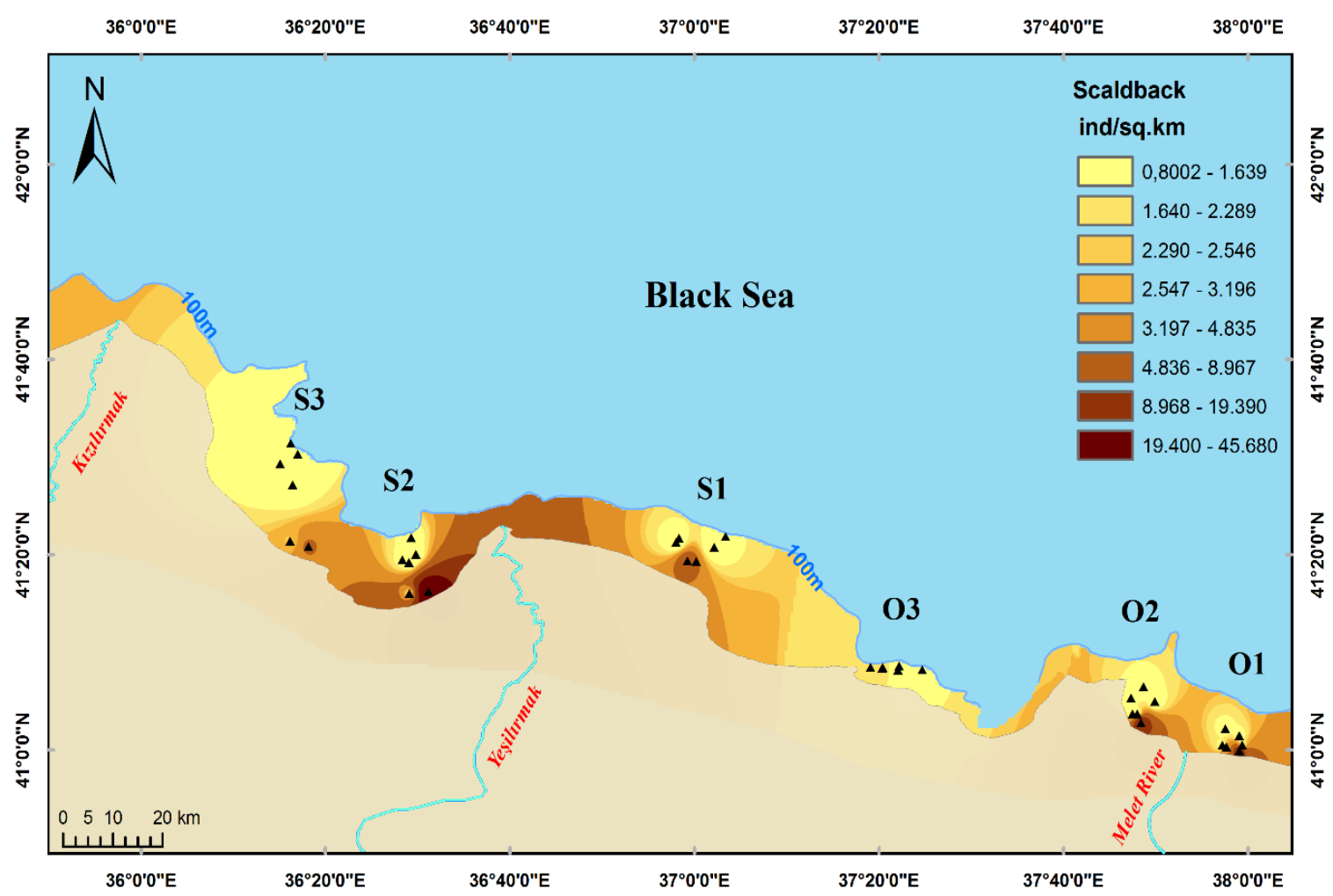

Figure 6. The mean density map of the scaldback along MSA and KYSA shelf areas 


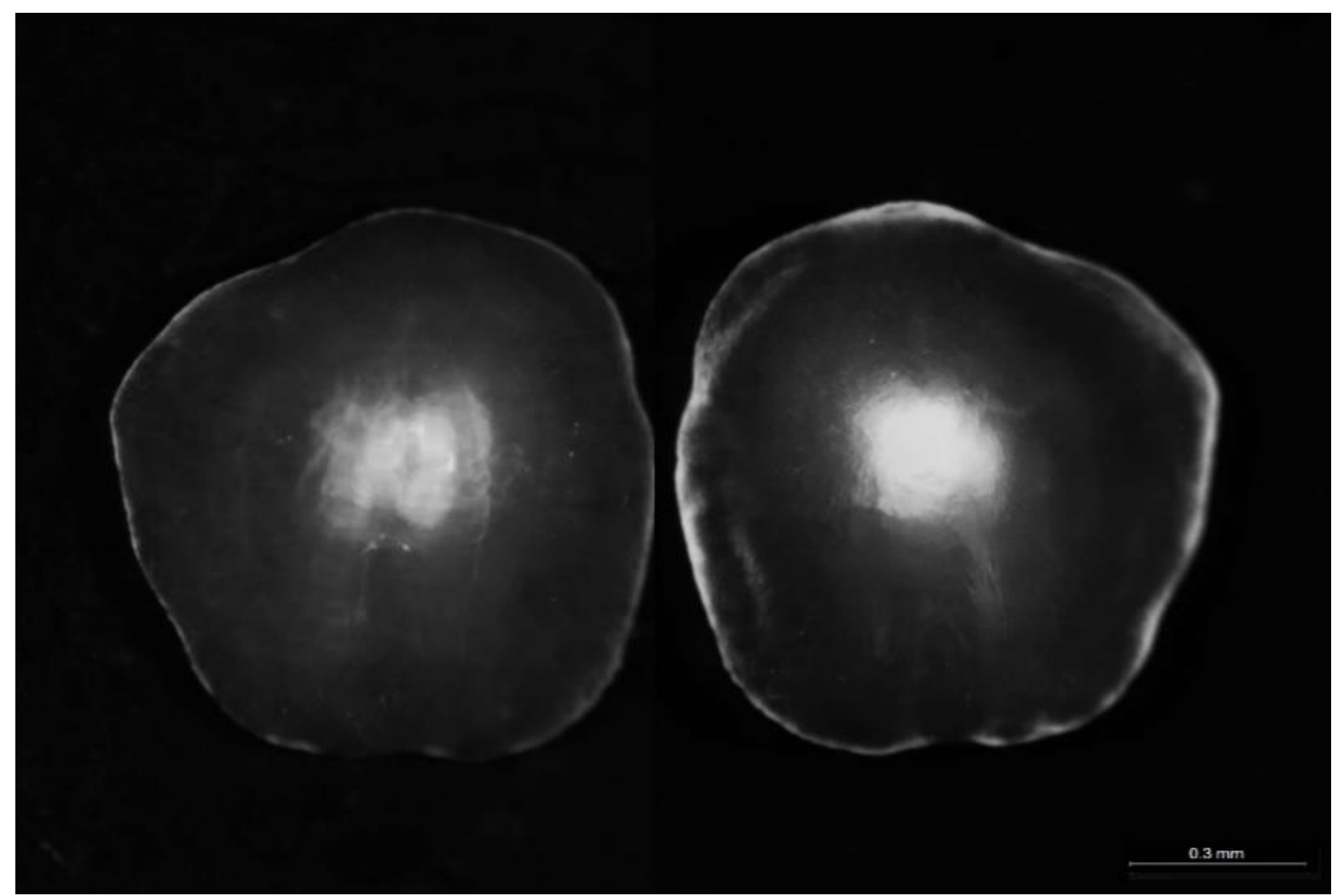

Figure 7. The morphology of the otolith of a scaldback specimen $(5.0 \mathrm{~cm} \mathrm{TL}$ and $1.12 \mathrm{~g} \mathrm{~W})$ from distal and proximal surface (Otolith length $=0.969 \mathrm{~mm}$ and otolith width $=0.828 \mathrm{~mm}$ )

\section{DISCUSSION}

This study aimed to display the otolith descriptions for a potential background to stomach content studies of carnivorous fish species and to demonstrate the distributions of three prey species in the southern Black Sea shelf with additional ecological information.

The transparent goby is one of the smallest species in the Gobiidae family. The maximum total length in the samples in this study was recorded as $5.8 \mathrm{~cm}$, and positive allometry ( $a=0.002 b=3.751$ $\mathrm{N}=567$ ) was detected in the L-W relationship. Iglesias et al. (1997) also recorded a range of total length of 1.2 and $4.9 \mathrm{~cm}$ and a positive allometric $(a=0.00071 b=3.55 \mathrm{~N}=1965) \mathrm{L}-\mathrm{W}$ relationship for the transparent goby distributed along the Island of Majorca (the northwest Mediterranean). It is reported that the maximum length for the transparent goby is $6.0 \mathrm{~cm}$ which was rarely reached in the Lagoon of Nador (Morocco) (Ramdani et al., 2016). Veiga et al. (2009) recorded $6.9 \mathrm{~cm}$ as the highest total length and a strong positive allometric $(a=0.0039 b=3.31 \mathrm{~N}=124) \mathrm{L}-\mathrm{W}$ relationship in the population sampled from the Arade estuary (southern Portugal). La Mesa (1999) found that the length range was between $1.3-5.5 \mathrm{~cm}$ with a $\mathrm{L}_{\text {inf }}$ of $6.87 \mathrm{~cm}$ and positive allometry $(a=0.00088 b=3.47$ $\mathrm{N}=245$ for the whole population) in the L-W relationship.

The seasonal values of the mean total length may give information about the one-year lifespan of the transparent goby. In this study, the highest mean length was recorded in the spring $(4.66 \mathrm{~cm})$, and it gradually decreased in summer $(3.75 \mathrm{~cm})$ and reached its lowest value in the fall $(3.57 \mathrm{~cm})$, indicating the new recruitment in late spring and early summer. The mean length increased in winter $(4.10 \mathrm{~cm})$ reaching its maximum in spring. La Mesa (1999) explained by monthly length-weight analysis that two cohorts are displayed in late spring and early summer.

The transparent goby distribution has a wide depth range from the sea surface to $80-100 \mathrm{~m}$ (Miller, 1986b). La Mesa (1999) sampled the population at a depth range of 10-40 $\mathrm{m}$ in the Adriatic Sea. In this study, the transparent goby was sampled through the depths of $0-60+\mathrm{m}$ with different intensities. The highest abundance was at depths of $0-30 \mathrm{~m}$ and especially in winter, probably the result of the schooling behavior of the species. Hence, it is reported that transparent goby enters an "aggregated phase" in winter (Auteri et al., 2000).

Tuset et al. (2008) described the otolith shape of transparent goby as squared. But the samples in this study that indicate an external morphology as discoidal/elliptical are more compatible with the 
report of La Mesa (1999). The transparent goby is known to be a very short-lived fish species (La Mesa, 1999). The life span of nearly one year may explain the weak growth ring formations. Iglesias et al. (1997) investigated the otoliths of the transparent goby in detail and reported that sagittal otoliths are disc-shaped in small individuals and transform to slightly oval as the fish get larger. It has also been discovered that otoliths lack a "settling mark," unlike most of the otoliths of the other goby species as a natural result of the pelagic lifestyle of the adults.

The marbled goby is a small-sized species. The total length range was determined as between 2.5$6.5 \mathrm{~cm}$ and the L-W relationship as a positive allometric $(a=0.005 b=3.175 \mathrm{~N}=716)$ in this study are compatible with previous records. Verdiell-Cubedo et al. (2006) reported the length range of the population as between $1.4-5.5 \mathrm{~cm}$ and the L-W relationship as a positive allometric $(a=0.00756 \mathrm{~b}=$ $3.150 \mathrm{~N}=1710$ ) in the Mar Menor coastal lagoon (the western Mediterranean Sea). The length range was recorded as between $1.2-6.7 \mathrm{~cm}$ with an L-W relationship of positive allometry $(a=0.005 \mathrm{~b}=$ $3.168 \mathrm{~N}=1678$ ) (Altin et al., 2015) in the northern Aegean Sea. Koutrakis and Tsikliras (2009) reported a sex-based length range for the marbled goby as 2.5-6.0 cm for males and 2.8-5.7 cm for females in the Strymon River estuarine system (northern Greece).

The marbled goby was found to be distributed along the depths of $0-60+\mathrm{m}$ in the sampling area. Though it typically inhabits inshore waters, Miller (1986b) reported that it can spread into depths of 70 $\mathrm{m}$ in winter. Furthermore, in this study, it was observed that larger individuals prefer deeper waters while the smaller ones were more abundant in shallow zones.

The density maps also indicated that the population has higher intensities per area in the KYSA, having a substrate type of muddy sand at maximum depths of 30-60 m. Malavasi et al. (2005) reported that the marbled goby avoids seagrass habitats and is mostly seen in muddy flats and salt marsh creeks in Venice Lagoon. In the same region, Franco et al. (2006) indicated that the marbled goby has higher intensities along sparsely vegetated and unvegetated mudflats. The marbled goby is one of the major components of bycatch with Gobius niger in the bottom trawl operations in the study area, and its mean abundance is $7159 \mathrm{~N} \cdot \mathrm{km}^{-2}$ within the sampling region. The short life span, opportunistic feeding strategy, and resistance to temperature variations and salinity may enhance the adaptation of the marbled goby to its environment (Fouda, 1995). All of this information implies that the life traits and the abundance value of marbled goby may have a definitive role in the ecosystem in which it exists.

The otolith characteristic of marbled goby was described as a discoidal form by Tuset et al. (2008). The finding of this study regarding the otolith shape of the marbled goby is compatible with the report of Tuset et al. (2008). Mazzoldi and Rossotto (2001) observed the otolith edge feature as opaque from October to March and hyaline from April in marbled goby otoliths.

The scaldback is a small-sized species with a mean total length of $5.4 \mathrm{~cm}$ for the sampled population in the southern Black Sea. It appears at a significant rate as a bycatch species in bottom trawl fisheries. Though it has been caught as a commercial species in the northern Black Sea until the mid-1970s (Shiganova, 1998), currently it has no commercial value.

In this study, the length range was determined as 2.9-12.8 cm. Furthermore, an isometric relationship was estimated between L-W variables $(a=0.009 b=3.005 \mathrm{~N}=528)$. Cakir et al. (2008) reported the length range as between $5.2-9.5 \mathrm{~cm}$ and a L-W relationship with parameters $a$ and $b$ as $4.10^{-6}$ and 3.1243 respectively $(\mathrm{N}=32)$ in Edremit Bay (the north Aegean Sea). Cakir et al. (2003) defined negative allometry for the L-W relationship $(a=0.0174 b=2.6824 \mathrm{~N}=32)$ for a similar length range and the same sampling region. Ilkyaz et al. (2008) recorded the length range between 6.9-9.6 $\mathrm{cm}$ for the scaldback with an isometric LWR $(a=0.0185 b=2.74 \mathrm{~N}=7)$ in the central Aegean Sea. Altin et al. (2015) reported a positive allometric LWR $(a=0.005 b=3.292 \mathrm{~N}=393)$ while Bayhan et al. (2008) recorded a negative type $(a=0.0179 b=2.601 \mathrm{~N}=76)$ for the Aegean Sea. Here, it seems that the LWR of the scaldback is highly variable in the Aegean Sea. On the other hand, the only other record from the eastern Black Sea is in accordance with the findings of this study since the length range was as 4.3-9.8 cm and an isometric type of LWR ( $a=0.021 b=2.984 \mathrm{~N}=60)$ (Ak et al., 2009).

There is no certain information about the schooling habits of the scaldback. According to the sampling observations in this study, it is highly possible that the individuals aggregate and form schools, especially around depths of 30-35 m, in fall and winter. The distribution of the scaldback was between 0-60 $\mathrm{m}$ in the sampling area but intensified at a depth zone of 0-30 m. Cakir et al. (2003) reported the distribution depth around 5-80 m for Edremit Bay (the north Aegean Sea) and Keskin (2012) as $24 \mathrm{~m}$ in the south-western Black Sea shelf. 
The mean density for the scaldback was determined as 6738 N.km${ }^{-2}$ within 114 experimental trawl operations (hauling with blind nets) while Keskin (2012) estimated the density as 114 N.km${ }^{-2}$ and the biomass as $0.36 \mathrm{~kg} \cdot \mathrm{km}^{-2}$ in bottom trawl operations (hauling with a mesh size of $16 \mathrm{~mm}$ cod-end) along the south-western Black Sea shelf.

\section{CONCLUSION}

Here, the main problem seems to be the disappearance of these small-sized species from the stomach contents of many piscivorous species due to fast digestion. The overlooking of otoliths, which are the only remaining part of the prey organisms, is very possible. Since the scaldback and the transparent goby otoliths are quite small and transparent, the risk of missing them in stomach content analysis is reasonably high. The otoliths are species-specific, and they are hard to digest for many predators. There is no other record for the otolith descriptions of these three species distributed along the southern Black Sea shelf, and they have never been mentioned in studies regarding the stomach content of carnivorous or piscivorous species though it is well known that they share a habitat with many species. This study may contribute to the definition of the transparent goby, the marbled goby, and the scaldback in future studies of feeding conducted on the southern shelf of the Black Sea.

Acknowledgments: This study is performed by Central Fisheries Research Institute (CFRI) under the name "Monitoring of Trawl Fisheries in The Black Sea (TAGEM/HAYSÜD/2010/09/01/04)" with the cooperation of Ondokuz Mayıs University (OMU).

\section{REFERENCES}

Aguilar-Perera, A., \& Quijano-Puerto, L. (2016). Relations between fish length to weight, and otolith length and weight, of the lionfish Pterois volitans in the Parque Nacional Arrecife Alacranes, southern Gulf of Mexico. Journal of Marine Biology \& Oceanography, 5, 469-474. https://doi.org/10.4067/S071819572016000200025

Ak, O., Kutlu, S., \& Aydin, I. (2009). Length-weight relationship for 16 fish species from the Eastern Black Sea, Türkiye. Turkish Journal of Fisheries and Aquatic Sciences, 9, 125-126.

Altin, A., Ayyildiz, H., Kale S., \& Alver C. (2015). Length-weight relationships of forty-nine fish species from shallow waters of Gökçeada Island, northern Aegean Sea Turkey. Turkish Journal of Zoology, 39, 971975. https://doi.org/10.3906/zoo-1412-15

Apostolou, A., Ivanova, P., Velkov, B., Vassilev, M., Dobrev D., \& Dobrovolov, I. (2011). Pomatoschistus marmoratus (RISSO 1810), is it really a "new" species for Bulgarian ichthyofauna. Acta Zoologica Bulgarica, 63, 289-294.

Auteri, R., Froglia C., \& Relini, G. (2000). Pesca del "rossetto" Aphia minuta De Buen 131 (stagioni 1995-1996 e 1996-1997) nei compartimenti marittimi di Imperia, Savona, Genova, La Spezia, Viareggio, Livorno e Pescara. Biologia Marina Mediterranea, 7, 99-105.

Avsar, D. (2001). Age, growth, reproduction and feeding of the spurdog (Squalus acanthias Linnaeus, 1758) in the south-eastern Black Sea. Estuarine, Coastal and Shelf Science, 52, 269-278. https://doi.org/10.1006/ecss.2000.0749

Baremore, I.E., \& Bethea, D.M. (2010). A guide to otoliths from the fishes of the Gulf of Mexico. NOAA Technical Memorandum NMFS-SEFSC-599, 102 pp.

Bariche, M., Alwan, N., El-Assi, H., \& Zurayk, R. (2009). Diet composition of the Lessepsian bluespotted cornetfish Fistularia commersonii in the eastern Mediterranean. Journal of Applied Ichthyology, 25, 460465. https://doi.org/10.1111/j.1439-0426.2008.01202.x

Battaglia, P., Andaloro, F., Consoli, P., Esposito, V., Malara, D., Musolino, S., Pedà, C., \& Romeo, T. (2013). Feeding habits of the Atlantic bluefin tuna, Thunnus thynnus (L. 1758), in the central Mediterranean Sea (Strait of Messina). Helgoland Marine Research, 67, 97-107. https://doi.org/10.1007/s10152-012-0307-2

Bayhan, B., Sever, T.M., \& Taskavak, E. (2008). Length-weight relationships of seven flatfishes (Pisces: Pleuronectiformes) from Aegean Sea. Turkish Journal of Fisheries and Aquatic Sciences, 8, 377-379.

Bethea, D.M., Buckel, J.A., \& Carlson, J.K. (2004). Foraging ecology of the early life stages of four sympatric shark species. Marine Ecology Progress Series, 268, 245-264. https://doi.org/10.3354/meps268245

Bilecenoglu, M., Kaya, M., Cihangir, B., \& Cicek, E. (2014). An updated checklist of the marine fishes of Turkey. Turkish Journal of Zoology, 38, 901-929. https://doi.org/10.3906/zoo-1405-60

Breitburg, D.L. (1991). Settlement patterns and presettlement behavior of the naked goby, Gobiosoma bosci, a temperate oyster reef fish. Marine Biology, 109, 213-221. https://doi.org/10.1007/BF01319389

Campana, S. E. (2004). Photographic atlas of fish otoliths of the Northwest Atlantic Ocean Canadian special publication of fisheries and aquatic sciences No. 133. NRC Research press. 
Chesalin, M.V., Zuev, G.V., \& Chesalina, T.L. (2004). Transparent goby Aphia minuta (Gobiidae) in the pelagic zone of the Black Sea. Journal of Ichthyology, 44, 587-591.

Cakir, D.T., Akalin, S., Unluoglu, A., Bayhan, B., \& Hossucu, B. (2003). The flatfish species in Edremit Bay and length-weight relationships for three of them Citharus linguatula (Linnaeus, 1758), Arnoglossus laterna (Walbaum, 1792), Arnoglossus kessleri (Schmidt, 1915). Ege Journal of Fisheries and Aquatic Sciences, 20, 529-536.

Cakir, D.T., Torcu-Koc, H., Basusta, A., \& Basusta, N. (2008). Length-weight relationships of 24 fish species from Edremit Bay Aegean Sea. e-Journal of New World Sciences Academy, 3, 47-51.

Elliott, M.L., Bradley, R.W., Robinette, D.P., \& Jahncke, J. (2015). Changes in forage fish community indicated by the diet of the Brandt's cormorant (Phalacrocorax penicillatus) in the central California Current. Journal of Marine Systems, 146, 50-58. https://doi.org/10.1016/j.jmarsys.2014.07.015

Engin, S., \& Seyhan, K. (2010). Age, growth, reproduction and diet of the Flatsnout Goby, Neogobius platyrostris (Pallas, 1814), on the south-eastern Black Sea Coast of Turkey: (Pisces: Gobiidae). Zoology in the Middle East, 50, 59-66. https://doi.org/10.1080/09397140.2010.10638412

Fouda, M.M. (1995). Life history strategies of four small-size fishes in the Suez Canal, Egypt. Journal of Fish Biology, 46, 687-702. https://doi.org/10.1111/j.1095-8649.1995.tb01104.x

Fitch, J. E., \& Brownell Jr, R. L. (1968). Fish otoliths in cetacean stomachs and their importance in interpreting feeding habits. Journal of the Fisheries Board of Canada, 25(12), 2561-2574. https://doi.org/10.1139/f68227

Fortunatova, K.R. (1949). Biology and feeding of the scorpion fish. Trudy Sevastopol Biological Station, 7, 193235.

Franco, A., Franzoi, P., Malavasi, S., Riccato, F., \& Torricelli, P. (2006). Fish assemblages in different shallow water habitats of the Venice Lagoon. Hydrobiologia, 555, 159-174. https://doi.org/10.1007/s10750-0051113-5

Froese, R. (2006). Cube law, condition factor and weight-length relationships: History, meta-analysis and recommendations. Journal of Applied Ichthyology, 22, 241-253. https://doi.org/10.1111/j.14390426.2006.00805.x

Iglesias, M., Brothers, E.B., \& Morales-Nin, B. (1997). Validation of daily increment deposition in otoliths. Age and growth determination of Aphia minuta (Pisces: Gobiidae) from the northwest Mediterranean. Marine Biology, 129, 279-287. https://doi.org/10.1007/s002270050168

Ilkyaz, A.T., Metin, G., Soykan, O., \& Kinacigil, H.T. (2008). Length-weight relationship of 62 fish species from the Central Aegean Sea, Turkey. Journal of Applied Ichthyology, 24, 699-702. https://doi.org/10.1111/j.1439-0426.2008.01167.x

Kartrip, (2013). Monitoring of Trawl Fisheries in The Black Sea, project number: TAGEM/ HAYSUD/2010/09/01/04. Fisheries Management (A09. P-01).

Kasapoglu, N., \& Duzgunes, E. (2015). Otolith atlas for the Black Sea. Journal of Environmental Protection and Ecology, 16, 133-144.

Kaya, S., \& Saglam, H. (2017). Feeding habits of garfish, Belone belone euxini Günther, 1866 in autumn and winter in Turkeys south-east coast of the Black Sea. Animal Biodiversity and Conservation, 40, 99-102. https://doi.org/10.32800/abc.2017.40.0099

Keskin, C. (2012). A preliminary study on demersal fishes in the south-western Black Sea shelf (NW Turkey). Journal of the Black Sea / Mediterranean Environment, 18, 341-349.

Koutrakis, E.T., \& Tsikliras, A.C. (2009). Reproductive biology of the marbled goby, Pomatoschistus marmoratus (Pisces, Gobiidae), in a northern Aegean estuarine system (Greece). Folia Zoologica, 58, 447-456.

La Mesa, M. (1999). Age and growth of Aphia minuta (Pisces, Gobiidae) from the central Adriatic Sea. Scientia Marina, 63, 147-155. https://doi.org/10.3989/scimar.1999.63n2147

La Mesa, M., Arneri, E., Caputo, V., \& Iglesias, M. (2005). The transparent goby, Aphia minuta: review of biology and fisheries of a paedomorphic European fish. Reviews in Fish Biology and Fisheries, 15, 89109. https://doi.org/10.1007/s11160-005-1613-4

Lin, C.H., \& Chang, C.W. (2012). Otolith Atlas of Taiwan Fishes. National Museum of Marine Biology and Aquarium, Pingtung, NMMBA Atlas Series 12, 415 pp.

Malavasi, S., Franco, A., Fiorin, R., Franzoi, P., Torricelli, P., \& Mainardi, D. (2005). The shallow water gobiid assemblage of the Venice Lagoon: abundance, seasonal variation and habitat partitioning. Journal of Fish Biology, 67, 146-165. https://doi.org/10.1111/j.0022-1112.2005.00919.x

Mazzoldi, C., \& Rasotto, M.B. (2001). Extended breeding season in the marbled goby, Pomatoschistus marmoratus (Teleostei: Gobiidae), in the Venetian Lagoon. Environmental Biology of Fishes, 61, 175183.

Miller, P.J. (1986a). Gobiidae. In: P.J.P. Whitehead, M.L. Bauchot, J.C. Hureau, J. Nielsen, E. Tortonese (Ed). Fishes of the North-Eastern Atlantic and the Mediterranean (pp 1019-1085), Vol III, Paris: UNESCO. 
Miller, P.J. (1986b). The functional ecology of small fish: some opportunities and consequences. Symposia of the Zoological Society, 69, 175-199.

Nielsen, J.G. (1986). Bothidae. In: P.J.P. Whitehead, M.L. Bauchot, J.C. Hureau, J. Nielsen, E. Tortonese (Ed). Fishes of the North-Eastern Atlantic and the Mediterranean (pp 1294-1298), Vol III, Paris: UNESCO.

Ramdani, M., Elkhiati, N., \& Layachi, M. (2016). Biology and ecology of the transparent goby Aphia minuta (RISSO, 1810) in the lagoon of Nador (Morocco). Rapport Commission Internationale pour l'exploration Scientifique de la Mer Méditerranée, 41, 343.

Samsun, S., Erdem, Y., \& Kalayci, F. (2011). Feeding regime of whiting (Gadus merlangus euxinus Nordmann, 1840) in Turkish middle Black Sea coast. Turkish Journal of Fisheries and Aquatic Sciences, 11, 515522.

Shiganova, T.A. (1998). Invasion of the Black Sea by the ctenophore Mnemiopsis leidyi and recent changes in pelagic community structure. Fisheries Oceanography, 7, 305-310. https://doi.org/10.1046/j.13652419.1998.00080.x

Sparre, P., \& Veneme, S.C. (1992). Introduction to tropical fish stock assessment (Part 1). FAO Fisheries Technical Paper, Rome.

Tuset, V. M., Lombarte, A., \& Assis, C.A. (2008). Otolith atlas for the western Mediterranean, north and central eastern Atlantic. Scientia Marina, 72, 7-198. https://doi.org/10.3989/scimar.2008.72s17

Veiga, P., Machado, D., Almeida, C., Bentes, L., Monteiro, P., Oliveira, F., Ruano, M., Erzini, K., \& Gonçalves, J.M.S. (2009). Weight-length relationships for 54 species of the Arade estuary, southern Portugal. Journal of Applied Ichthyology, 25, 493-496. https://doi.org/10.1111/j.1439-0426.2009.01230.x

Verdiell-Cubedo, D., Oliva-Paterna, F.J., \& Torralva, M. (2006). Length-weight relationships for 22 fish species of the Mar Menor coastal lagoon (western Mediterranean Sea). Journal of Applied Ichthyology, 22, 293294. https://doi.org/10.1111/j.1439-0426.2006.00738.x

Viva, C., Sartor, P., Bertolini, D., De Ranieri, S., \& Ligas, A. (2015). Relationship of otolith length to fish total length in six demersal species from the NW Mediterranean Sea. Journal of Applied Ichthyology, 31, 973974. https://doi.org/10.1111/jai.12838 